\title{
EL PRINCIPIO DEL FIN: LAS VACUNAS CONTRA SARS-COV-2
}

\author{
THE BEGINNING OF THE END: SARS-COV-2 VACCINES \\ O COMEÇO DO FIM: VACINAS SARS-COV-2
}

Hugo Luis Pizzi ${ }^{1}$

En Berkeley Inglaterra en1749 nace Edward Jenner, el hombre que cambió la historia de la medicina.

En 1796 ya siendo médico visitaba tambos y observaba con espíritu crítico, las pústulas de las ordeñadoras ocasionadas por la viruela vacuna. En esa época morían anualmente en el mundo 9 millones de personas.

Jenner sabía por Lady Montagu (esposa del embajador ingles en Turquía) que allí inoculaban desde 1721 virus de lesiones de viruela humana. Si bien algunos se inmunizaban, un gran número moría.

En sus visitas a las ordeñadoras, una de ellas le dijo que no tenía miedo a la viruela porque estaba protegida por la contaminación vacuna. A ella le pidió que permitiera inocular con material de sus pústulas a su hijo de 8 años James Phipps, el niño tuvo fiebre leve que supero en días.

Meses más tarde al mismo niño, lo inoculó con viruela humana y James no contrajo la enfermedad .Estaba en los prolegómenos del más grande descubrimiento de la época. Y por haber trabajado con ganado bovino y viruela vacuna; a partir de ese día se denominó al tratamiento inmunizante VACUNA. Jenner plasmó en un escrito su experiencia "Investigación sobre las causas y los efectos de la viruela vacuna" y lo mandó a la "Asociación médica de Londres". Esta rechazó el hallazgo aduciendo que los pacientes podían convertirse en ganado vacuno.

El verdadero impacto del aporte de Jenner llegó en 1805, cuando Napoleón Bonaparte ordenó vacunar a toda su tropa, según lineamientos del inglés.

Este descubrimiento fue fruto de la capacidad de sopesar situaciones epidemiológicas del médico de Berkeley. En esa época no había posibilidad de ver los microorganismos. La etapa de poder visualizarlos llega gracias a Robert Koch y Louis Pasteur que abrieron la puerta de lo microscópico: Antrax 1881, Rabia 1882, Tétanos 1890, Difteria 1890, Peste Bubónica 1897.

Esto permitió empezar a fabricar vacunas a virus vivos, muertos, atenuados y las acelulares; sin embargo la revolución en el diseño de las mismas irrumpe en los últimos años.

\section{Las vacunas que llegan a nuestro país.}

1- Universidad Nacional de Córdoba. Facultad de Ciencias Médicas

Recibido: 2020-12-02 Aceptado: 2020-12-02

DOI: $\underline{\text { http://dx.doi.org/10.31053/1853.0605.v77.n4.31138 }}$

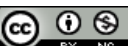

(C) Universidad Nacional de Córdoba
La primera sería la vacuna rusa Sputnik $V$ desarrollada en el prestigioso instituto Nicolay Gamaleya; este centro de investigación moscovita lleva el nombre de uno de los discípulos de Louis Pasteur. Gamaleya trabajó en Francia, junto a su maestro en el desarrollo de la vacuna antirrábica y otras líneas de hallazgos muy importantes para la humanidad. Cuando vuelve a Rusia dirige luchas sanitarias contra cólera, difteria y tifus. En 1886 Rusia fue el segundo país en aplicar la vacuna antirrábica, según lineamientos aprendidos en París.

En 1949 el gobierno ruso nacionaliza el instituto privado y lo transforma en el Centro Nacional Nicolay Gamaleya, que depende del ministerio de defensa.

Este centro diseñó en 2015 dos vacunas muy exitosas: Ébola y Mers (coronavirus que asoló medio oriente trasmitido por camellos y dromedarios) Este esquema utilizaron los sabios del Gamaleya para construir la Sputnik V. Dicha vacuna consta de dos vectores, ambos adenovirus humanos a los que se les incorporó el gen que codifica para glicoproteína spike de virus SarsCoV-2. Estos adenovirus son el A26 que se inocula en la primera dosis y el A5 en la segunda reforzando el efecto inmunizador. Debe conservarse a menos 18.5 grados. 
La segunda es la vacuna inglesa desarrollada en el Instituto Edward Jenner en la Universidad de Oxford con el apoyo del Laboratorio sueco-inglés Astra Zeneca.

La vacuna de Oxford está diseñada con adenovirus de chimpancé modificados con una nano glicoproteína $\mathrm{S}$. Al inocularse el sistema defensivo reacciona como si fuese el coronavirus, sin riesgo de provocar la enfermedad. Concomitantemente aumenta el interferón, elevando la respuesta de inmunidad celular "T".

Esta vacuna debe inocularse en dos dosis y debe conservarse entre 2 y 8 grados bajo cero.

La Tercera vacuna es la Pfizer Biontech que utiliza una novedosa estrategia de ARN mensajero sintético, obtenido por ingeniería genética, con una nano glicoproteína S optimizada. Es una copia de la secuencia del virus, que una vez inoculado va a los ribosomas de las células, produciendo antígenos similares al virus y por lo tanto, dando respuesta inmune. Se inocula en dos dosis como las anteriores y necesita menos 75 grados centígrados para su conservación.

Estas tres vacunas que serán utilizadas en Argentina, además de representar lo más moderno en su tipo, aumentan los anticuerpos en un rango inédito superior al 90 por ciento, algo inimaginable cuando durante muchos años inyectábamos vacunas que estimulaban mucho menos.

La operación de distribución y logística, estará a cargo de los ministerios nacionales de Salud y Defensa, que delegarán en los ministerios provinciales la inoculación.

La Universidad Nacional de Córdoba a través de la Facultad de Ciencias Médicas, aportará 5000 voluntarios para la campaña (siguiendo colaborando desde el primer día de la pandemia).

La campaña nacional fue denominada "Operación General Manuel Belgrano." No hay dudas que estamos en otra era de las inmunizaciones y se avizora en El horizonte el principio del fin de esta tragedia que dejó una retahíla de secuelas y un cambio de hábitos. 